Original Article

Artigo Original

\title{
Pain in popular singers
}

\section{Dor em cantores populares}

\section{Descritores}

Dor

Voz

Distúrbios da voz Treinamento da voz Música

\section{Correspondence address:}

Clara Rocha

Av. Rebouças, 1332/52, Pinheiros, São

Paulo (SP), Brasil, CEP: 05402-100.

E-mail: claracrds@yahoo.com.br

Received: 2/24/2011

Accepted: 9/28/2011

\begin{abstract}
Purpose: To identify and characterize the presence of body pains in popular singers, to observe the differences in the reported pains according to gender, and to relate with data regarding vocal behavior and usage in this population. Methods: A self-explanatory questionnaire was applied to 100 popular singers (50 men and 50 women), in order to collect information about personal identification, voice use and presence of pains. Pains were divided into two groups: proximal pains (TMA, tongue, throat, nape, shoulders, neck, and pain during speech), and distal pains (arms, back/column, chest, hands, ear, and headache). Results: The mean value of pain presence referred by popular singers was 2.9. There was no difference in reported pain according to gender. Predominant pains were on the throat (66\%), during speech (41\%) and on the neck (35\%), all classified as proximal to the larynx. The least predominant pains were in arms, hands and chest (4\%), all classified as distal pains. Conclusion: Popular singers reported presence of body pains mainly proximal to the larynx. There is no difference in reported pain according to gender. The presence of body pain is related to the presence of voice disorders, the need to stop singing, the absence of vocal training, and search for professional advice (otolaryngologists and speech-language pathologist) due to vocal problems. These data justify the investigation and attention to body pain symptoms by the professionals responsible for the treatment of this population.
\end{abstract}

\section{RESUMO}

Objetivo: Identificar e caracterizar a presença de dores corporais em cantores populares, verificar se há diferença no relato de dor de acordo com o gênero e relacionar com dados referentes a questões vocais e de uso da voz desta população. Métodos: Aplicou-se um questionário autoexplicativo em 100 cantores populares (50 homens e 50 mulheres) que investigou questões referentes a identificação pessoal, uso de voz e presença de dor. As dores foram divididas em dois grupos: dores proximais (ATM, língua, garganta, nuca, ombros, pescoço e para falar) e dores distais (braços, costas/coluna, peito, mãos, ouvido e dor de cabeça). Resultados: A média da presença de dor referida entre os cantores populares foi de 2,9 dores. Não houve diferença no relato de dor de acordo com o gênero. As dores predominantes foram dor de garganta (66\%), dor ao falar (41\%) e dor no pescoço $(35 \%)$, todas classificadas como proximais à laringe. As dores menos predominantes foram dor nos braços, mãos e peito (4\%), sendo todas estas classificadas como distais. Conclusão: Cantores populares referem presença de dores corporais, principalmente proximais à região da laringe. Não há diferença no relato de dor de acordo com o gênero. Há relação entre a presença de dor corporal e presença de problemas vocais, necessidade de parar de cantar, falta de treinamento vocal e procura de otorrinolaringologista e fonoaudiólogo por problemas de voz. Estes dados justificam uma investigação e valorização de sintomas de dor pelos profissionais que atendam a esta população.

Research performed at Centro de Estudos da Voz - CEV - São Paulo (SP), Brasil.

(1) Graduate Specialization in Voice, Centro de Estudos da Voz - CEV - São Paulo (SP), Brazil.

(2) Centro de Estudos da Voz - CEV - São Paulo (SP), Brazil.

Conflict of interests: None 


\section{INTRODUCTION}

According to the International Association for Study of Pain - IASP, pain may be defined as "the unpleasant sensitive and emotional experience associated or related to a real lesion or tissue potential"(1). The Sociedade Brasileira de Estudo da Dor-SBED (Brazilian Society of Pain Study) adds that pain is an important symptom caused by a disease, an organic affection, or even a more complex clinic state, which primarily alerts the person to the need of assistance ${ }^{(2)}$.

Vocal signs and symptoms are, in clinical practice, many times associated to the presence of body pain. Whenever voice is used in an inappropriate set, using effort, tension or lack of technique in professional voice users' case, the person might relate discomfort and pain to phonation, restricting voice income. This pain receives the name of odinophonia and it is considered a symptom of voice disturbance ${ }^{(3)}$.

Recently, a study about presence of body pain in general population was developed and, the results showed that women reported higher occurrence of pain when compared to men and, the most reported pain to both genders were in the back $(56.3 \%)$, throat $(51.1 \%)$ and, head $(49.2 \%)^{(4)}$. Another study, comparing the presence of body pain in classic singers with general population data, revealed the average classic singers pain are lower than the pain in general population, including the region next to larynx, as head (18\%), neck (26\%) and shoulders $(30 \%)$. Only sore throat was higher between these singers (56\%) and the general population data (51.1\%), perhaps due to major attention given to this location or appreciation of any discomfort at the throat. These low values of pain may suggest that vocal training, usual in this singing style, acts as a protection to the presence of pain in this population ${ }^{(5)}$.

To understand the behavior and habits of singers is important to clinical management; however, there are few publications about this theme and the most of it are about classic singers, with specific vocal training, remaining a low part of the studies involving popular singing, a generic term to define all the non-classic singing or lyric. Nowadays, the term Commercial Contemporary Music - CCM is used to describe generically several music styles as rock, Brazilian popular music, pop, samba, pagode, gospel, country, jazz, blues and others, eliminating the pejorative "non-classic music"(6). This singing type does not necessarily demands a formal vocal training due to the proximity of many styles to speech setting, taking these singers to low search of singing lessons and, many times showing injurious vocal habits ${ }^{(7)}$, besides of singing in unfavorable environmental conditions (noisy environment, inappropriate acoustic setting, smoke, and others) and showing more tension during the execution of determined singing styles ${ }^{(8)}$ when compared to classic singers. The excessive number of singing coupled up to all the factors previously mentioned might contribute to an increase of referred pain, particularly in the region next to the larynx. Therefore it was chosen to investigate the presence of pain in a broad group, singing different kinds of music styles, dealing with diverse singing settings and showing different vocal demand and training.

The purposes of this study were to identify and characterize the presence of body pain in popular singers, to verify if there is difference in pain report according to gender and to relate the data to vocal issues and voice usage of this population.

\section{METHODS}

The present research was approved by the Ethical Committee of Centro de Estudos da Voz (CEV) under the protocol number 0517/09.

A self-explanatory questionnaire was applied in 100 popular singers (50 men and 50 women), Brazilians, living in diverse states of the country and volunteers to the research. It was not performed any calculus to define the size of sample. It was chosen to have a similar composition between men and women and these singers must embrace several styles and situation in popular singing.

The used questionnaire was based on previous researches ones in order to investigate the relation between voice and pain in teachers, and in general population ${ }^{(4,9)}$. It was made the changes which characterize the reality to popular singers population.

Each participant answered to the questionnaire about personal identification, voice usage, and presence of pain. The questions regarding identification and voice usage were: age range; years of singing practice; amount of singing hours per week; singing lessons; amount of time doing singing lessons; place used to sing; environment settings, music style; whether had had vocal problems during singing; whether had had the need to stop singing; whether had looked for an otolaryngologist due to vocal disturb; whether had looked for a speech language pathologist due to vocal disturb; and voice self-evaluation.

The questions regarding body pain investigated the presence of 13 pain kind, categorized in two groups: proximal to the larynx pain - headache, ATM/jaw pain, tongue pain, sore throat, nape pain, shoulders pain, neck pain, and pain to speak - and distal pain - back/spine pain, chest pain, arms pain, hands pain, and ears pain.

The main data about sample characteristics are available in Chart 1.

To determine the frequency of pain, the participants used a five-point scale to respond: never, sometimes, often, almost always and always. However, to compute the data, the answers were categorized as presence of pain (sometimes, often, almost always and always) and absence (never).

The data was submitted to statistical analysis using the test for Equality of Proportions between two samples to characterize the qualitative variables percentage distribution, to distribute the absence or presence of each kind of pain in studied population and to compare these results between genders. To relate body pain presence with the amount of places, styles and singing setting reported by singers the Mann-Whitney test was used. Finally, the Chi-Square Test for Independence was used to relate the presence of pain with the following variables: singing lessons, vocal problems during singing, stop singing due to vocal problems, physician and speech language pathologist appointment due to vocal problems and vocal self-evaluation. The adopted significance level was 0.05 . 
Chart 1. Characterization data from the studied sample

\begin{tabular}{|c|c|c|c|}
\hline \multicolumn{2}{|l|}{ Variables } & \multirow{2}{*}{$\begin{array}{c}n \\
8 \\
67 \\
17 \\
8\end{array}$} & \multirow{2}{*}{$\begin{array}{c}\% \\
8 \\
67 \\
17 \\
8 \\
\end{array}$} \\
\hline Age range & $\begin{array}{l}20 \text { years or less } \\
21 \text { to } 40 \text { years } \\
41 \text { to } 50 \text { years } \\
\text { Over } 51 \text { years }\end{array}$ & & \\
\hline $\begin{array}{l}\text { Years of } \\
\text { practice }\end{array}$ & $\begin{array}{l}1 \text { to } 5 \text { years } \\
6 \text { to } 10 \text { years } \\
11 \text { to } 15 \text { years } \\
16 \text { to } 20 \text { years } \\
21 \text { years or more }\end{array}$ & $\begin{array}{l}26 \\
37 \\
11 \\
10 \\
15\end{array}$ & $\begin{array}{l}26 \\
37 \\
11 \\
10 \\
15 \\
\end{array}$ \\
\hline $\begin{array}{l}\text { Hours per week } \\
\text { of singing }\end{array}$ & $\begin{array}{l}0 \text { to } 2 \text { hours } \\
2 \text { to } 4 \text { hours } \\
4 \text { to } 6 \text { hours } \\
6 \text { to } 8 \text { hours } \\
\text { More than } 8 \text { hours }\end{array}$ & $\begin{array}{c}6 \\
25 \\
31 \\
23 \\
15\end{array}$ & $\begin{array}{c}6 \\
25 \\
31 \\
23 \\
15\end{array}$ \\
\hline Singing lessons & $\begin{array}{l}\text { Did have lessons } \\
\text { Did not have lessons } \\
\text { Women who had lessons } \\
\text { Men who had lessons } \\
\text { Less than } 1 \text { year of lessons } \\
1 \text { to } 5 \text { year of lessons } \\
6 \text { to } 10 \text { years of lessons } \\
\text { More than } 10 \text { years of lessons }\end{array}$ & $\begin{array}{c}78 \\
22 \\
44 \\
34 \\
21 \\
39 \\
10 \\
8\end{array}$ & $\begin{array}{c}78 \\
22 \\
88 \\
68 \\
26.9 \\
50 \\
12.8 \\
10.3 \\
\end{array}$ \\
\hline $\begin{array}{l}\text { Places of } \\
\text { presentation }\end{array}$ & $\begin{array}{l}\text { Show houses } \\
\text { Bars } \\
\text { Churches } \\
\text { Others (recording studio, events, } \\
\text { theater, etc) }\end{array}$ & $\begin{array}{l}44 \\
43 \\
17 \\
37\end{array}$ & $\begin{array}{l}44 \\
43 \\
17 \\
37\end{array}$ \\
\hline $\begin{array}{l}\text { Singing } \\
\text { situation }\end{array}$ & $\begin{array}{l}\text { Solo } \\
\text { Band } \\
\text { Vocal group } \\
\text { Choir } \\
\text { Backing vocal } \\
\text { Others } \\
\end{array}$ & $\begin{array}{c}49 \\
47 \\
19 \\
17 \\
16 \\
1\end{array}$ & $\begin{array}{c}49 \\
47 \\
19 \\
17 \\
16 \\
1\end{array}$ \\
\hline Musical styles & $\begin{array}{l}\text { BPM - Brazilian Popular Music } \\
\text { Rock } \\
\text { Pop } \\
\text { Country } \\
\text { Samba/Pagode } \\
\text { Gospel } \\
\text { Forró/reggae } \\
\text { Axé } \\
\text { Others }\end{array}$ & $\begin{array}{l}61 \\
36 \\
31 \\
17 \\
15 \\
13 \\
8 \\
4 \\
6\end{array}$ & $\begin{array}{c}61 \\
36 \\
31 \\
17 \\
15 \\
13 \\
8 \\
4 \\
6\end{array}$ \\
\hline $\begin{array}{l}\text { Amount of } \\
\text { places to sing }\end{array}$ & $\begin{array}{l}1 \text { place } \\
2 \text { places } \\
3 \text { or more places }\end{array}$ & $\begin{array}{c}62 \\
35 \\
3\end{array}$ & $\begin{array}{c}62 \\
35 \\
3 \\
\end{array}$ \\
\hline $\begin{array}{l}\text { Amount of } \\
\text { environmental } \\
\text { settings }\end{array}$ & $\begin{array}{l}1 \text { setting } \\
2 \text { settings } \\
3 \text { or more settings }\end{array}$ & $\begin{array}{l}63 \\
27 \\
10\end{array}$ & $\begin{array}{l}63 \\
27 \\
10\end{array}$ \\
\hline $\begin{array}{l}\text { Amount of } \\
\text { singing styles }\end{array}$ & $\begin{array}{l}1 \text { style } \\
2 \text { styles } \\
3 \text { or more styles }\end{array}$ & $\begin{array}{l}55 \\
26 \\
19\end{array}$ & $\begin{array}{l}55 \\
26 \\
19\end{array}$ \\
\hline Voice Problems & $\begin{array}{l}\text { Experienced vocal problems } \\
\text { during singing } \\
\text { Stopped singing due to a vocal } \\
\text { problem } \\
\text { Looked for an otolaryngologist } \\
\text { due to voice problem } \\
\text { Looked for a speech language } \\
\text { pathologist due to a voice problem }\end{array}$ & $\begin{array}{l}61 \\
27 \\
47 \\
40\end{array}$ & $\begin{array}{l}61 \\
27 \\
47 \\
40\end{array}$ \\
\hline $\begin{array}{l}\text { Voice self- } \\
\text { evalutaion }\end{array}$ & $\begin{array}{l}\text { Excellent } \\
\text { Very good } \\
\text { Good } \\
\text { Reasonable } \\
\text { Bad }\end{array}$ & $\begin{array}{c}9 \\
39 \\
43 \\
9 \\
0\end{array}$ & $\begin{array}{c}9 \\
39 \\
43 \\
9 \\
0\end{array}$ \\
\hline
\end{tabular}

\section{RESULTS}

The mean pain value between popular singers was 2.9 pains. Mean values of men and women did not show difference between each other ( 2.7 to women and 3.2 to men, $\mathrm{p}=0.274$ ).

Table 1 shows the values regarding the presence and absence of the 13 researched pains between genders and total mean. The predominant pains in popular singers were sore throat $(66 \%)$, followed by pain to speak (41\%), and neck pain (35\%), all classified as proximal to larynx. The low predominant pains were arms pain, hands pain, and chest pain (4\%), all classified as distal to larynx. There was no difference in the pain report according to gender, however the value indicates tendency of men to report more sore throat than women (74\% against $58 \%, \mathrm{p}=0.091$ ).

There weren't relation among the amount of places, environmental settings, and musical style with the presence of body pain (Table 2 ).

Comparing the presence of different kinds of pains with the practice of singing lessons (table 3 ), it was observed that $100 \%$ of the women who did not have sore throat had made singing lessons and $79 \%$ of the women with sore throat have not made singing lessons ( $\mathrm{p}=0.026$ ).

In table 4 it was observed a statistical tendency in the relation between sore throat and vocal self-evaluation which $57 \%$ of women without sore throat classified their voices as $\operatorname{good}(\mathrm{p}=0.051)$. There was statistical association between sore throat and presence of voice problems during singing practice, i.e. among the singers reporting sore throat $69 \%$ of women and $76 \%$ of men also reported vocal disturbances. Another correlating data were: $80 \%$ of women with nape pain had vocal disturbances; $53 \%$ of women with shoulder pain have already needed to stop singing; $76 \%$ of women had already looked for an otolaryngologist; and $65 \%$ of the women had already looked for a speech language pathologist due to voice disturbances.

Among people with pain to speak, $89 \%$ of women and $83 \%$ of men have voice disturbances, $56 \%$ of women and $35 \%$ of men had already to stop singing, $72 \%$ of women and $61 \%$ of men had already looked for an otolaryngologist, and $67 \%$ of women had already looked for a speech language pathologist due to vocal problems.

Although the presence of distal pain showed to be low, it was observed that all women with ear pain $(n=3)$ had already to stop singing; all men with chest pain $(n=3)$ had already to stop singing and $50 \%$ of men reporting arms pain classified their voices as reasonable.

\section{DISCUSSION}

The presence of pain in singers might compromise the professional exercise and negatively impact the quality of life. Currently, the specifics self-evaluation questionnaires are used in vocal clinic and they have shown to be sensitive to this population, however they do not have question related to pain ${ }^{(10-12)}$. The pain complaint, especially proximal ones, in singers may be a symptom associated to tension, to inappropriate voice usage and, perhaps, may be a factor predisposing the generation of 
Table 1. Body pain, proximal and distal to larynx, in popular singers according to gender

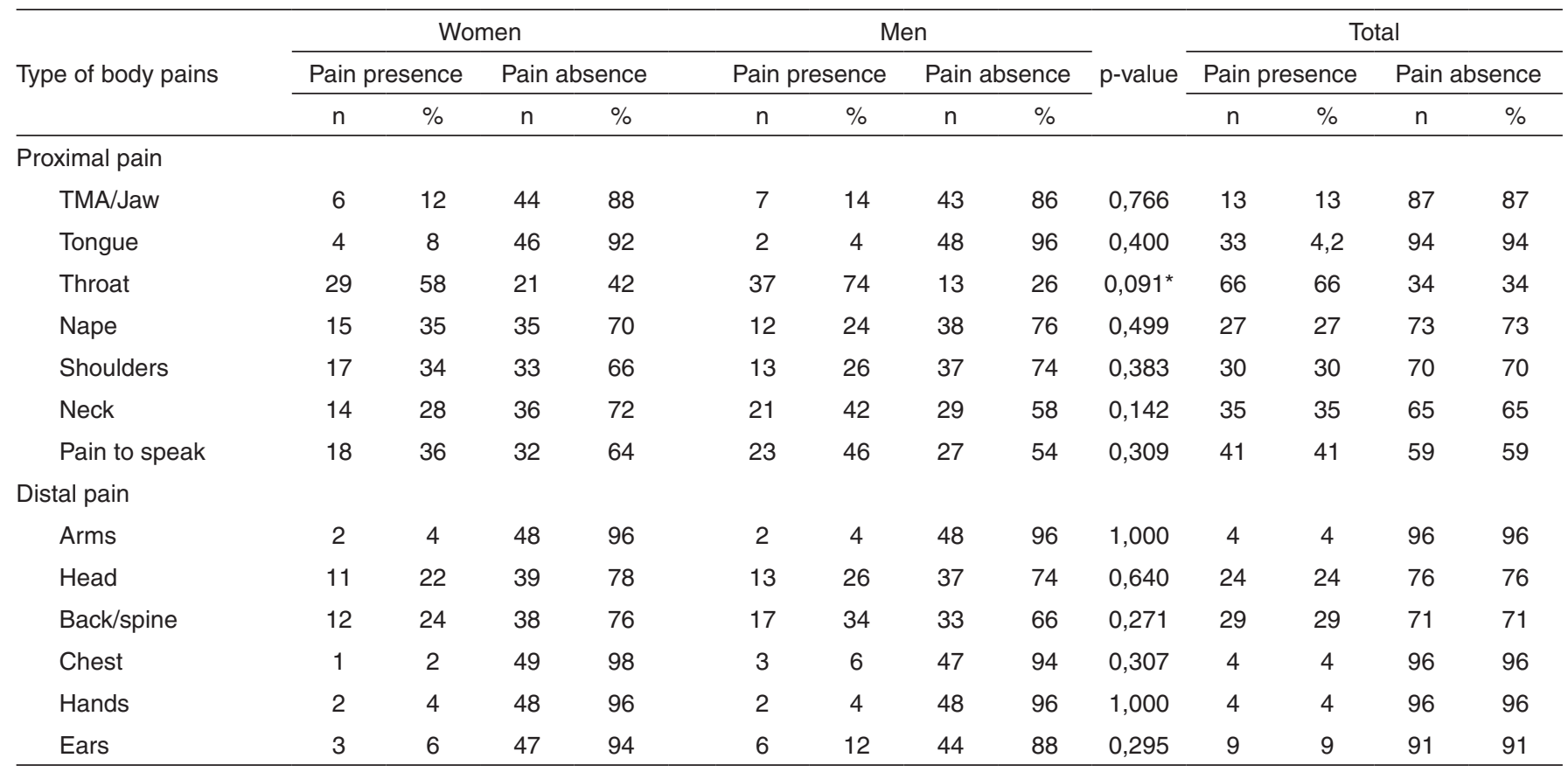

*Value with statistical tendency $(p \leq 0.05)-$ Equality of Two Proportions test

Table 2. Pain regarding amount of places which singers present their selves, environment settings and singing style

\begin{tabular}{|c|c|c|c|c|c|c|c|c|c|c|}
\hline \multirow{2}{*}{ Pain } & & \multicolumn{3}{|c|}{ Amount of places } & \multicolumn{3}{|c|}{ Amount of settings } & \multicolumn{3}{|c|}{ Amount of styles } \\
\hline & & Mean & $\mathrm{n}$ & $p$-value & Mean & $\mathrm{n}$ & $p$-value & Mean & $\mathrm{n}$ & $\mathrm{p}$-value \\
\hline Head & No & 1.42 & 76 & 0.853 & 1.53 & 76 & 0.375 & 1.91 & 76 & 0.500 \\
\hline \multirow{2}{*}{ TMA } & No & 1.44 & 87 & \multirow{2}{*}{0.220} & 1.51 & 87 & \multirow{2}{*}{0.606} & 1.93 & 87 & \multirow{2}{*}{0.256} \\
\hline & Yes & 1.23 & 13 & & 1.38 & 13 & & 1.77 & 13 & \\
\hline Tongue & No & 1.40 & 94 & 0.973 & 1.48 & 94 & 0.980 & 1.94 & 94 & 0.254 \\
\hline \multirow{2}{*}{ Throat } & No & 1.41 & 34 & \multirow{2}{*}{0.976} & 1.47 & 34 & \multirow{2}{*}{0.759} & 1.74 & 34 & \multirow{2}{*}{0.806} \\
\hline & Yes & 1.41 & 66 & & 1.50 & 66 & & 2.00 & 66 & \\
\hline \multirow{2}{*}{ Nape } & No & 1.38 & 73 & \multirow{2}{*}{0.420} & 1.52 & 73 & \multirow{2}{*}{0.429} & 1.92 & 73 & \multirow{2}{*}{0.931} \\
\hline & Yes & 1.48 & 27 & & 1.41 & 27 & & 1.89 & 27 & \\
\hline Shoulders & No & 1.40 & 70 & 0.783 & 1.56 & 70 & 0.159 & 1.90 & 70 & 0.910 \\
\hline Neck & No & 1.46 & 65 & 0170 & 1.62 & 65 & 0 012* & 1.95 & 65 & 0.538 \\
\hline ivech & Yes & 1.31 & 35 & 0.170 & 1.26 & 35 & 0.012 & 1.83 & 35 & 0.000 \\
\hline Chest & No & 1.42 & 96 & 0.568 & 1.49 & 96 & 0813 & 1.93 & 96 & 0861 \\
\hline טาง & Yes & 1.25 & 4 & 0.000 & 1.50 & 4 & 0.016 & 1.50 & 4 & 0.00 \\
\hline Arms & No & 1.42 & 96 & 0568 & 1.49 & 96 & 0813 & 1.94 & 96 & 0335 \\
\hline भा⿵冂卄一 & Yes & 1.25 & 4 & 0.000 & 1.50 & 4 & 0.070 & 1.25 & 4 & 0.000 \\
\hline Hands & No & 1.39 & 96 & $0014^{*}$ & 1.47 & 96 & 0106 & 1.86 & 96 & * \\
\hline tianus & Yes & 2.00 & 4 & 0.014 & 2.00 & 4 & 0.100 & 3.00 & 4 & $0.0<v$ \\
\hline Fars & No & 1.41 & 91 & 0744 & 1.48 & 91 & 0961 & 1.96 & 91 & 589 \\
\hline
\end{tabular}

* Significant values $(p \leq 0.05)-$ Mann-Whitney test 
Table 3. Relation between singing lessons and sore throat according to gender

\begin{tabular}{|c|c|c|c|c|c|c|c|c|}
\hline \multirow{2}{*}{ Singing lessons } & & \multicolumn{2}{|c|}{ No } & \multicolumn{2}{|c|}{ Yes } & \multicolumn{2}{|c|}{ Total } & \multirow{2}{*}{$p$-value } \\
\hline & & $\mathrm{n}$ & $\%$ & $\mathrm{n}$ & $\%$ & $\mathrm{n}$ & $\%$ & \\
\hline \multirow{2}{*}{ Women } & No & 0 & 0 & 6 & 21 & 6 & 12 & \multirow{2}{*}{$0.026^{*}$} \\
\hline & Yes & 21 & 100 & 23 & 79 & 44 & 88 & \\
\hline \multirow{2}{*}{ Men } & No & 3 & 23 & 13 & 35 & 16 & 32 & \multirow{2}{*}{0.423} \\
\hline & Yes & 10 & 77 & 24 & 65 & 34 & 68 & \\
\hline
\end{tabular}

* Significant values $(p \leq 0.05)$ - Chi-Square for Independence test

Table 4. Relation between body pain, according to gender, voice self-evaluation, need to stop singing, voice problems during singing, otolaryngologist appointment and/or speech language pathologist appointment due to voice disturbance

\begin{tabular}{|c|c|c|c|c|c|}
\hline & Voice self-evaluation & Stop singing & Voice problems & ENT appointment & SLP appointment \\
\hline & $p$-value & $p$-value & $p$-value & p-value & $\mathrm{p}$-value \\
\hline \multicolumn{6}{|l|}{ Women } \\
\hline Headache & 0.726 & 0.602 & 0.563 & 0.733 & 0.912 \\
\hline TMA pain & 0.281 & 0.447 & 0.752 & 0.384 & 0.150 \\
\hline Tongue pain & 0.866 & 0.363 & 0.801 & 1.000 & 0.801 \\
\hline Sore throat & $0.051^{* *}$ & 0.416 & $0.030^{*}$ & 0.774 & 0.890 \\
\hline Nape pain & 0.117 & 0.312 & $0.025^{*}$ & 0.355 & 0.384 \\
\hline Shoulders pain & 0.878 & $0.011^{*}$ & 0.136 & $0.007^{*}$ & $0.034^{*}$ \\
\hline Back pain & 0.241 & $0.001^{*}$ & 0.128 & $0.008^{*}$ & $0.070^{\star *}$ \\
\hline Neck pain & 0.470 & $0.054^{\star \star}$ & 0.171 & $0.012^{*}$ & $0.072^{\star *}$ \\
\hline Chest pain & 0.754 & 0.508 & 0.371 & 0.312 & 0.371 \\
\hline Arms pain & 0.950 & 0.529 & 0.861 & 1.000 & 0.861 \\
\hline Hands pain & 0.485 & 0.529 & 0.861 & 0.149 & 0.861 \\
\hline Ear pain & 0.771 & $0.006^{*}$ & 0.113 & $0.074^{\star *}$ & 0.415 \\
\hline Pain to speak & 0.590 & $0.003^{*}$ & $<0.001^{*}$ & $0.018^{*}$ & $0.015^{*}$ \\
\hline \multicolumn{6}{|l|}{ Men } \\
\hline Headache & 0.881 & 0.506 & 0.334 & 0.856 & 0.375 \\
\hline TMA pain & 0.114 & 0.109 & 0.235 & 0.375 & 0.684 \\
\hline Tongue pain & 0.334 & 0.417 & 0.300 & 0.103 & 0.674 \\
\hline Sore throat & 0.551 & 0.110 & $0.015^{\star}$ & 0.264 & 0.648 \\
\hline Nape pain & 0.343 & 0.100 & 0.450 & $0.070^{\star *}$ & 0.639 \\
\hline Shoulders pain & 0.732 & 0.928 & 0.100 & 0.406 & 0.119 \\
\hline Back pain & 0.930 & 0.520 & 0.262 & 0.773 & 0.584 \\
\hline Neck pain & 0.874 & 0.979 & 0.933 & 0.661 & 0.390 \\
\hline Chest pain & 0.188 & $0.001^{*}$ & 0.980 & 0.701 & 0.180 \\
\hline Arms pain & $0.043^{*}$ & 0.380 & 0.300 & 0.861 & 0.279 \\
\hline Hands pain & 0.126 & 0.103 & 0.300 & 0.103 & 0.674 \\
\hline Ear pain & 0.645 & 0.568 & 0.971 & 0.752 & 0.466 \\
\hline Pain to speak & 0.550 & $0.099^{* *}$ & $0.022^{*}$ & $0.027^{*}$ & 0.309 \\
\hline
\end{tabular}

* Significant values $(\mathrm{p} \leq 0.05)-$ Chi-Square for Independence test

** Values with statistical tendency $(p \leq 0.05)$ - Chi-Square for Independence test

Note: ENT = ear, nose and throat; SLP = speech-language pathology; TMA = temporomandibular articulation

larynx alterations, prejudicing their vocal health.

Popular singers have mean value of 2.9 pains, and this data when compared to lyrical singers mean value (2.4 pains) show little difference. When comparing to general population, mean value equal 4.2 pains, it is observed that the value to popular singers is lower ${ }^{(4,5)}$. This data may suggest that popular singer, as well as lyrical singer, may have a good vocal training, knowledge about vocal health, and an accurate perception about their own voices, making a healthier voice usage, and consequently decreasing pain report. Besides, the singing practice may be a protective factor to pain ${ }^{(5)}$ and yet increase the person quality of life and less inclinable to pain complaints in general. The low index of pain found in this population might as well be related to the fact of $50 \%$ of sample was submitted to one to five years of singing lessons.

It was not observed a statistical difference of pain reported for both genders, the value presented just a statistical tendency in the comparison which men reporting more sore throat than women (74\% against 58\%, p=0.0091) (Table 1). In lyrical singers' study ${ }^{(5)}$ there were also no differences between men and women. The obtained data with popular and lyrical singers do not corroborate the data obtained to general population ${ }^{(4)}$, which 
the mean of pain in women is higher than men, suggesting that singing itself may reduce the amount of reported pain in general to both genders. Other studies about pain point out men and women are different regarding pain coping, threshold, and tolerance, women had higher complaints and lower resistance ${ }^{(13-15)}$.

Regarding predominant pains, the three most reported pains by popular singers were all proximal to larynx: sore throat (66\%), pain to speak (41\%), and neck pain (35\%). The less predominant pains were arms pain, hands pain, and chest pain (4\%), all classified as distal to larynx (Table 1). Excepting back pain $(29 \%)$ and headache (24\%), all the proximal pains were higher than distal pains. Singing, especially without appropriated training, might generate tension in muscles around the larynx, and consequently leading to pain in this region, however it was observed that most of sample (78\%) had some kind of vocal training, therefore, the singing practice and training make these people to have a more accurate perception about any disturbance related to their voices, e.g. a proximal pain to the larynx, justifying the higher occurrence of it. Lyrical singers ${ }^{(5)}$ also reported sore throat as predominant pain, possibly due to singers to be considered vocal elite, inside the level of vocal demand classification ${ }^{(16)}$, therefore a minimal alteration may represent a big problem in these subjects that often depend on voice in their profession. Another important data is the pain to speak to be in second place as predominant pain in popular singers, different from lyrical singers, and general population. Perhaps the proximity of many musical styles to speech setting may justify this result. Another hypothesis to be considered is that popular singers have a higher voice usage in speech because they need to network in order to improve their careers perhaps leading to the pain complaint during speech. However, the speech behavior of these singers was not investigated in the present research.

The increase in amount of places, environmental settings and musical style did not cause an increase in presence of proximal pain or in most prevalent pain in popular singers (Table 2 ), however this sample, in majority, sings only in one place, at one environmental setting or one musical style $(62 \%, 63 \%$, and $55 \%$ respectively). Perhaps a bigger number of participants reporting a higher amount of places, settings and musical style were necessary in order to relate these characteristics with presence of pain, since the literature shows people with higher vocal demand present in average higher index of vocal handicap in self-evaluation protocols suggesting that high demand may interfere on quality of life of a person who uses voice professionally ${ }^{(17)}$.

The results of Table 3 suggest singing lessons may reduce sore throat complaints since $100 \%$ of women who did not present sore throat have made singing lessons and $79 \%$ of women presenting sore throat have not made singing lessons $(\mathrm{p}=0.026)$. The literature shows that singers with vocal training when comparing to amateurs singers have more voice consciousness, more knowledge about larynx physiology and anatomic issues and about vocal hygiene ${ }^{(18)}$ pointing out, face the big number of voice disturbances involving singing voice patients, it is important to make multidisciplinary interventions aiming to maximize voice income, i.e. singing lessons may proportionate a appropriate voice use, more information about voice care improving voice health of the singer, and, consequently decreasing voice and proximal pain complaint during practice of singing.

It was observed relation between sore throat, pain to speak and nape pain with presence of voice problems (Table 4), as most of singers reporting these pains reported voice disturbance. These three pains are proximal to the larynx as sore throat and pain to speak the two most relevant pains to this population. Also, women with shoulders pain, back pain and pain to speak had already to stop singing. These data suggest proximal pain to larynx complaint are more resident in people reporting vocal problems and then pain next to the larynx region during the practice of singing might indicate the presence or predisposition to the urge of voice disturbances, and restricting singing activity. The presence of small voice deviation in a singer may bring big financial impact, shows and presentations canceled and restricting the professional exercise ${ }^{(10-20)}$.

In the studied sample there was a big search for otolaryngologists and speech language pathologists due to vocal disturbances and a correlation between the searches with the presence of body pains (Table 4). These correlations suggest the presence of proximal pains during the practice of singing, excepting back pain, leading the singer to seek for a professional voice treatment. As the impact of minimal voice deviation may be big in this population, singers inclined to be more alert to their own voices and searched proper treatment usually at the beginning of symptoms ${ }^{(10)}$.

The voice self-evaluation data shows the majority of singers classifying their own voices as good $(43 \%)$ and this data corroborates the one found to general population and lyric singers ${ }^{(4,5)}$. Thirty nine percent of singers classified their own voices as very good corroborating the data found to lyric singers ${ }^{(5)}$, suggesting that usually singers are satisfied with their own voices, otherwise they would not risk their selves singing in public.

The body pains, especially the proximal ones, whenever present during or after singing practice may generate discomfort and worries to singer, therefore pain must be investigated and valued to professionals treating this population, even to its low occurrence comparing to others professions.

\section{CONCLUSION}

Popular singers report presence of body pain predominating sore throat, pain to speak and neck pain, all proximal to larynx.

There is no relation between pain and gender.

There was relation between body pain and presence of voice disturbances, need to stop singing, lack of voice training, and search for otolaryngologist and speech language pathologist due to voice disorder.

These data justifies the investigation and value of pain symptoms to the professionals treating this population.

\section{REFERENCES}

1. IASP- International Association for the Study of Pain [cited 2008 Jan 28]. Disponível em: http://www.iasp-pain.org. 
2. SBED: Sociedade Brasileira para Estudos da Dor. [cited 2008 Jan 28] Disponível em: http://www.dor.org.br.

3. Brewer DW. Early diagnostic signs and symptoms of laryngeal disease. Laryngoscope. 1975;85(3):499-515.

4. Guerrieri AC, Behlau M. Dores corporais relacionadas ao uso da voz nos sexos masculino e feminino. In: $16^{\circ}$ Congresso Brasileiro de Fonoaudiologia; 2008; Campos de Jordão. Anais. Campos do Jordão: SBFa; 2008.

5. Vaiano T, Guerrieri AC, Behlau M. Dores corporais relacionadas ao uso da voz em coralistas líricos. In: $18^{\circ}$ Congresso Brasileiro de Fonoaudiologia; 2010; Curitiba. Anais. Curitiba: SBFa; 2010.

6. LoVetri J, Weekly E. Contemporary comercial music (CCM) survey: who's teaching what in non-classical music. J Voice. 2003;17(2):207-15.

7. Zampieri AS, Behlau M, Brasil OO. Análise dos cantores de baile em estilo de canto popular e lírico: perceptivo-auditiva, acústica, e da configuração laríngea. Rev Bras Otorrinolaringol. 2002;68(3):378-86.

8. Gonsalves A, Amin E, Behlau M. Análise do grau global e tensão na voz em cantores de roque. Pró-Fono. 2010;22(3):195-200.

9. Scheffel L. Presença de dores corporais relacionadas ao uso da voz em professores do ensino fundamental da rede escolar municipal da cidade de Novo Hamburgo-RS. [monografia]. 2006.

10. Rosen CA, Murry T. Voice handicap index in singers. J Voice. 2000;14(3):370-7.

11. Fussi F, Fuschini T. Foniatria artistica: la presa in carico foniatricologopedica del cantante classico e moderno. Audiologia \& Foniatria. 2008;13(1-2):4-28.
12. Moreti F, Rocha C, Borrego MC, Behlau M. Desvantagem vocal no canto: análise do protocolo Índice de Desvantagem para o Canto Moderno - IDCM. Rev Soc Bras Fonoaudiol. 2011;16(3):337-43.

13. Robinson ME, Gagnon CM, Riley 3rd JL, Price DD. Altering gender role expectations: effects on pain tolerance, pain threshold, and pain ratings. J Pain. 2003;4;(5):284-8.

14. Kogh E, Herdenfeldt M. Gender, coping and the perception of pain. Pain. 2002;97:195-201.

15. Kut E, Schaffner N, Wittwer A, Candia V, Brockmann M, Storck C, et al. Changes in self-perceived role identity modulate pain perception. Pain. 2007;Sep131;(1-2):191-201.

16. Koufman JA, Isaacson G. The spectrum of vocal dysfunction. Otolaryngol Clin North Am. 1991;24(5):985-8.

17. Beheman A, Sulica L, He T. Factors preditcting patient perception of dysphonia caused by benign vocal fold lesions. Laryngoscope. 2004;114(10):1693-700.

18. Mota LA, Santos CM, Barbosa KM, Neto JR. Disfonia em cantores: revisão da literatura. ACTA ORL/Técnicas em Otorrinolaringologia. 2010;28(1):27-31.

19. Braun-Janzen C, Zeine L. Singer's knowledge level of vocal function and disfunction. J Voice. 2009;23(4):470-83.

20. Murry T, Zschommler A, Prokop J. Voice handicap index in singers. J Voice. 2009;23(3):376-9. 